\title{
Migration from Nursery to Spawning Area in relation to growth and maturation of Greenland Halibut (Reinhardtius hippoglossoides) in the Northeast Arctic
}

\author{
Ole Thomas Albert \\ Norwegian Institute of Fisheries and Aquaculture \\ 9291 Tromsø, Norway
}

\begin{abstract}
The population structure of the concentrations of Greenland halibut (Reinhardtius hippoglossoides (Walbaum, 1792)) in relation to distribution area and state of maturity is described based on 12 trawl surveys conducted in the spawning, nursery and feeding areas along the Norwegian Continental Slope between October 1996 and January 1999. Based on these, inferences are made of how the migration from nursery to spawning area depends on individual characteristics, such as sex, maturity stage and previous growth history, and how emigration from nursery is linked to immigration to the spawning area. Descriptions are also given of the age and length structure of the different maturity groups in the spawning area. It was inferred that for both males and females, the fast growing individuals left the nursery first, and there was no obvious sex-difference in emigration rate from the nursery area. The early maturing females that are found along with those close to spawning have low growth rates and are thus not representative of all the next year's spawners, as previously suggested. Before spawning stock biomass can be realistically modelled, similar studies should also be made on the vertical component of migration and all the migration processes should be quantified.
\end{abstract}

Keywords: Greenland halibut, growth, maturation, migration, sampling

\section{Introduction}

Greenland halibut (Reinhardtius hippoglossoides (Walbaum, 1792)) in the Northeast Atlantic is categorized into several management units. Those occurring in the Barents Sea and along the coasts of Norway, including Svalbard, have been pragmatically defined as the Northeast Arctic stock. Its relation to stocks occurring in other parts of the Northeast Atlantic is not known. There has been much uncertainty relating to its dynamics and, accordingly, the annual assessments have been uncertain, resulting in much controversy between fishermen and management. The main distribution pattern of the stock is as follows: spawning is along the continental slope from Bear Island and southwards to the North Norwegian coast (Albert et al., 2001a). Eggs and larvae drift towards nursery grounds, which are at least partly found in Svalbard waters (Albert et al., 2001b; Bowering and Nedreaas, 2000). Larger juveniles and adults spread out in large parts of the Barents Sea from where the mature fish undertake spawning migrations to the slope (Godø and Haug, 1989).
Although this overall migration pattern is known, the dynamics of migration are not understood. It is not known how an individual fish migrates throughout its life, or how the distribution of a year-class changes with age, size and maturation stage. Understanding the specifics of fish migration is necessary in order to properly interpret sampling and survey data, and to weight samples from different localities if necessary, in order to get accurate age and maturity compositions of the stock. The age groups for which it is most important to know the distribution are those where the rate of maturation is highest, i.e. approximately age 6-12. More detailed knowledge concerning the dynamics of migration might help to explain anomalies in assessment data. For example, for several years there has been a regular inconsistency in the age-composition used in the assessments of the Northeast Arctic stock (ICES, 2001). One consequence is that age 9 has been estimated low in abundance for several consecutive years. This may not simply be an age-reading problem, but may as well be related to sampling relative to distribution of individual age groups. 
Albert et al. (2001a) showed that two very distinct groups of maturing females were present at the spawning grounds prior to and during spawning. One of these was characterized by ovaries filled with large (2-4 mm) eggs and represented those that were just about to spawn. The other group had ovaries filled with small $(<1 \mathrm{~mm})$ even-sized eggs. The status of this last group is uncertain. It may represent a second spawning event several months later in another spawning area, it may be the next year's spawners, or it may be females that are not completing the spawning process.

This paper is one in a series from a comprehensive study of the spawning and recruitment processes of Greenland halibut in the Barents Sea and the Eastern Norwegian Sea (Albert et al., 1997, 1998, 2001a, $2001 \mathrm{~b}$; Albert and Høines, in print; Gundersen et al., 2000; Stene et al., 1999; Ådlandsvik et al., 1999). The purpose of this paper is to further analyse the transition of Greenland halibut from immature to spawning condition. At what size and age do they migrate from the nursery to the spawning grounds? How does this migration depend on individual characteristics, such as sex, maturity stage and previous growth history? What characterizes the fishes that constitute the different maturity stages, in particular the early maturing females during the spawning season? Since we do not have enough direct observations of this migration from mark-recapture experiments, inferences about the migrations must be based on the sequence of demographic changes within and among areas and seasons.

\section{Material and Methods}

Greenland halibut was sampled from 12 research surveys of the spawning area along the Norwegian continental slope (Fig. 1) between October 1996 and January 1999. For the purpose of this paper, trawls were grouped in the four main areas - Spawning Area (Area 1), Barents Sea (Area 2), Svalbard South (Area 3 ) and Svalbard North (Area 4) - and the two time periods, October-February (the spawning period) and April-August. Table 1 gives an overview of the data and Fig. 1 shows the areas and distribution of trawls. This covers the main spawning region (Albert et al., 1998 ) in the three spawning seasons 1996-97, 199798 and 1998-99. Trawls were allocated to $50 \mathrm{~m}$ depth intervals between 450 and $900 \mathrm{~m}$ in each of six transects across the slope. In November 1997 trawls were also made in the Hopen Deep of the Barent Sea.
In addition, Greenland halibut was also sampled during annual routine surveys in the Barents Sea and Svalbard waters in the period April-August 1997-99. On these surveys, a few trawls were also allocated to the slope area. All trawls were made with a modified Campelen shrimp trawl towed by the R/V "Jan Mayen". Details of trawl equipment, procedures and sampling sites were given by Albert et al. (1998; 2001a) for the surveys to the Spawning Area, and by Aschan and Sunnanå (1997) for the annual routine surveys.

From each trawl haul, individual data were recorded for all Greenland halibut in the catch (Table 1). Total length was measured to the nearest $1 \mathrm{~cm}$ below, and round weight to nearest $1 \mathrm{~g}$. Maturity status was recorded by a standard four-level macroscopic maturation index (immature, maturing, running, and spent). In addition, for females, egg size and gonad weight was also recorded. Age was determined from otoliths. They were read whole under reflected light against a black background following recommended procedures (Anon., 1997; Bowering and Nedreaas, 2001).

As described by Albert et al. (2001a) the different measures of female maturity status were combined and a new modified maturity index, MMI, was defined based on the modal composition of log-transformed classes of the gonadosomatic index. This index identifies four distinct maturity stages of Greenland halibut in the spawning season. They may respectively be termed "Immature", with no visible eggs (by naked eye), "Early maturing", with evenly sized small eggs and apparently many months (perhaps a year) to go before spawning, "Close to spawning", with large eggs, and "Spent", without eggs but still distinctly different from the immature. In this paper the first two groups are sometimes collectively called juveniles, while the last two represent the mature individuals.

The 1-cm length intervals had to be pooled in larger intervals (into $2 \mathrm{~cm}$ units in Fig. 2 and 3) in order to make length distributions for sub-groups of individuals, e.g. age groups, maturity groups, for which total numbers were restricted. The pooled length groups were labelled with their midpoints. To compare length-at-age across age groups, frequency distributions of relative length groups were produced. Relative length-at-age of an individual was defined as the ratio of length to the mean length of the appropriate age group. Individuals were pooled in relative length groups of 0.05 . 


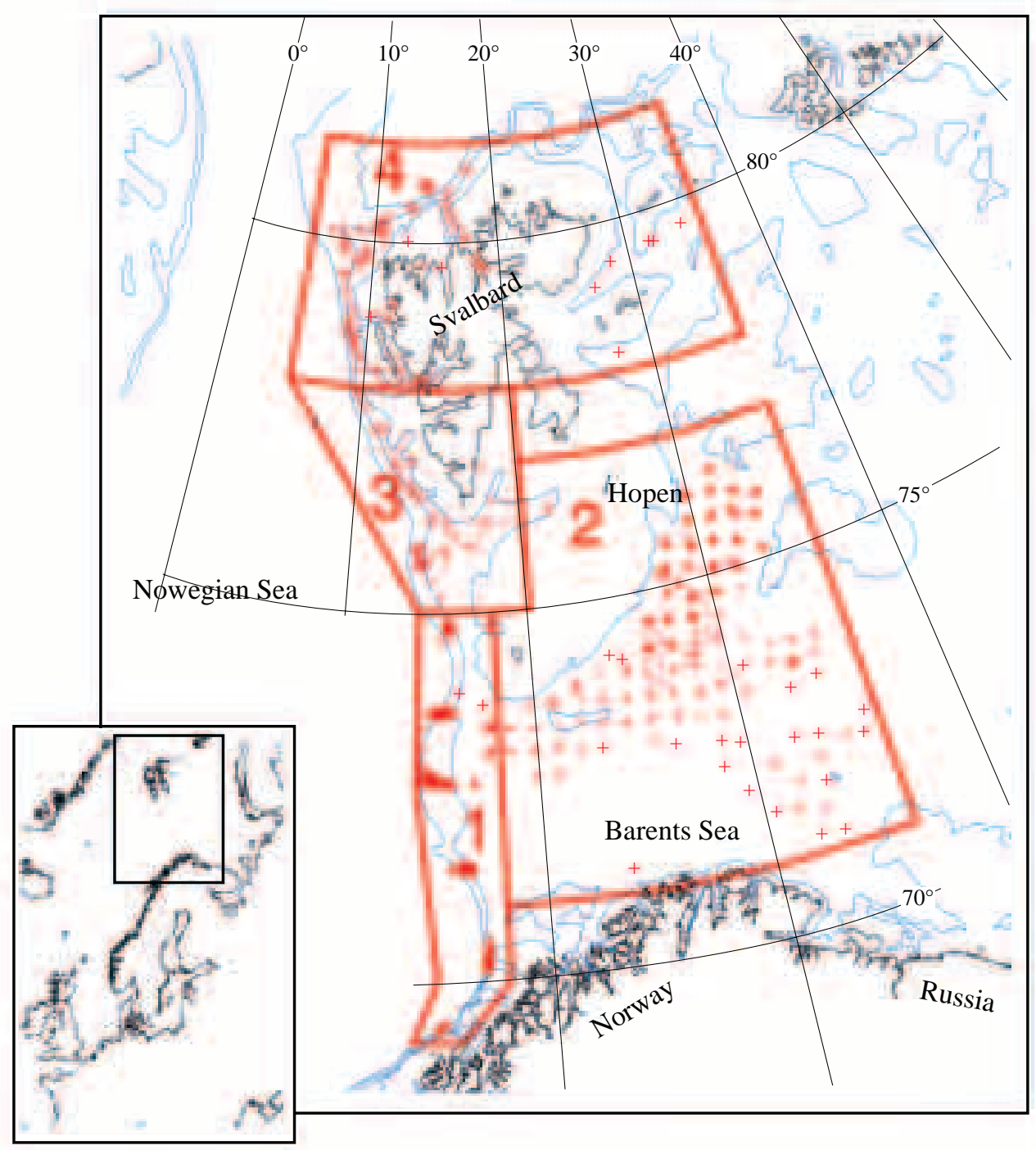

Fig. 1. Bathymetric map of the survey area with the 200, 500 and $1000 \mathrm{~m}$ isobaths indicated. Areas referred to in the text are 1: Spawning Area, 2: Barents Sea, 3: Svalbard South, and 4: Svalbard North. Each trawl haul sampled in April-August is marked with a cross, and those from October-January with a dot.

\section{Results}

\section{Length and maturity across area and season}

Females. Female Greenland halibut in Svalbard North (Area 4) were characterized by a predominance of small juveniles (Fig. 2). The first two length-modes were at 15 and $23 \mathrm{~cm}$ and a third one may be seen around $30 \mathrm{~cm}$, but not well separated from the second. $80 \%$ were below $40 \mathrm{~cm}$. Some smaller juveniles were also found in Svalbard South (Area 3) and Barents Sea (Area 2). In the Barents Sea area, $81 \%$ of females below $40 \mathrm{~cm}$ were found in the Hopen Deep, north of $74^{\circ} 30^{\prime} \mathrm{N}$.
In the Svalbard South and Barents Sea areas larger juveniles, in the range 40-70 cm, dominated (Fig. 2). In the Barents Sea area, only $20 \%$ of these larger fish were found in the Hopen Deep region. Mature individuals were recorded in low numbers, but among those larger than $60 \mathrm{~cm} 20-40 \%$ were classified as mature. These mature individuals were all recorded in the southern part of the areas. No mature females were recorded in Svalbard North.

In Spawning Area (Area 1) few fish were recorded below $40 \mathrm{~cm}$. During the spawning season the length frequency distribution of females was characterised by one major modal group of larger juveniles, in the 
TABLE 1. Number of individual Greenland halibut for which individual data were recorded.

\begin{tabular}{|c|c|c|c|c|c|c|c|c|}
\hline \multirow{2}{*}{$\begin{array}{l}\text { Area } \\
\text { number }\end{array}$} & \multirow[b]{2}{*}{ Name } & \multirow[b]{2}{*}{ Year } & \multicolumn{2}{|c|}{ Oct-Feb } & \multicolumn{2}{|c|}{ Apr-Aug } & \multicolumn{2}{|c|}{ Whole year } \\
\hline & & & Total & Aged & Total & Aged & Total & Aged \\
\hline \multirow[t]{4}{*}{1} & Spawning Area & 1996 & 681 & 255 & 249 & 68 & 930 & 323 \\
\hline & & 1997 & 4820 & 995 & - & - & 4820 & 995 \\
\hline & & 1998 & 1371 & 430 & 70 & 66 & 1441 & 496 \\
\hline & & 1999 & 848 & 236 & 3 & - & 851 & 236 \\
\hline \multirow[t]{4}{*}{2} & Barents Sea & 1996 & - & - & 451 & 2 & 451 & 2 \\
\hline & & 1997 & 87 & - & 392 & - & 479 & 0 \\
\hline & & 1998 & - & - & 558 & 12 & 558 & 12 \\
\hline & & 1999 & 9 & - & 494 & - & 503 & - \\
\hline \multirow[t]{4}{*}{3} & Svalbard South & 1996 & - & - & 156 & - & 156 & - \\
\hline & & 1997 & - & - & 7 & 6 & 7 & 6 \\
\hline & & 1998 & - & - & 646 & 28 & 646 & 28 \\
\hline & & 1999 & - & - & 367 & - & 367 & - \\
\hline \multirow[t]{4}{*}{4} & Svalbard North & 1996 & - & - & 383 & 263 & 383 & 263 \\
\hline & & 1997 & - & - & 554 & 132 & 554 & 132 \\
\hline & & 1998 & - & - & 645 & 45 & 645 & 45 \\
\hline & & 1999 & - & - & 436 & - & 436 & - \\
\hline Total & & & 7816 & 1916 & 5411 & 622 & 13227 & 2538 \\
\hline
\end{tabular}

range $40-70 \mathrm{~cm}$, and another consisting of mature individuals in the range $60-80 \mathrm{~cm}$ (Fig. 2). In the spawning period $41 \%$ of the females in this area were characterised as mature, while only $11 \%$ were similarly classified in the feeding period. In the other three area-period combinations percentage of mature females ranged from 0.3 to $4 \%$.

Males. The male Greenland halibut showed much the same length distribution pattern as the females, except the right-hand sides of the male distributions did not change very much from area to area or between seasons.

Small juveniles were mainly found in Svalbard North where they dominated the catches (Fig. 3). The first three length-modes were relatively well separated, more so than for the females. Ages 1-3 could be distinguished with modes at 13,21 and $30 \mathrm{~cm}$, respectively. The small juveniles were also found in Svalbard South and Barents Sea, mainly in the northern part of each area.

As for females, individual males above $40 \mathrm{~cm}$ dominated in all areas other than Svalbard North. In the Spawning Area, as was seen for the females, a separate mode of larger juvenile males could be distinguished that co-occurred with the mature individuals. However, unlike for the females the two groups did not comprise separate modes in the total length distribution. This is partly because the length difference was small and partly because, as in all areas, the larger juveniles $(>40 \mathrm{~cm})$ were outnumbered by the mature individuals.

The mature males were apparently more widely distributed than the mature females and were found in significant numbers in all areas and both seasons (Fig. 3).

\section{Comparison of age distributions for fish in Svalbard North and spawning area}

Females. In Svalbard North, most females were younger than 10 years, and in Spawning Area, age 910 represented the most common age groups of immature females (Fig. 4). The most common ages of mature females were 9-11 years and with increasing age relatively more were mature. The age composition of early maturing females resembled the mature females more than the immature, with more of the older ones and less of the younger individuals.

At the spawning grounds in October-January the mean length of females in maturity stages Immature, Early maturing, Close to spawning, and Spent were $53,58,64$, and $64 \mathrm{~cm}$ respectively. The distribution of relative length groups (Fig. 5) shows that Immature 


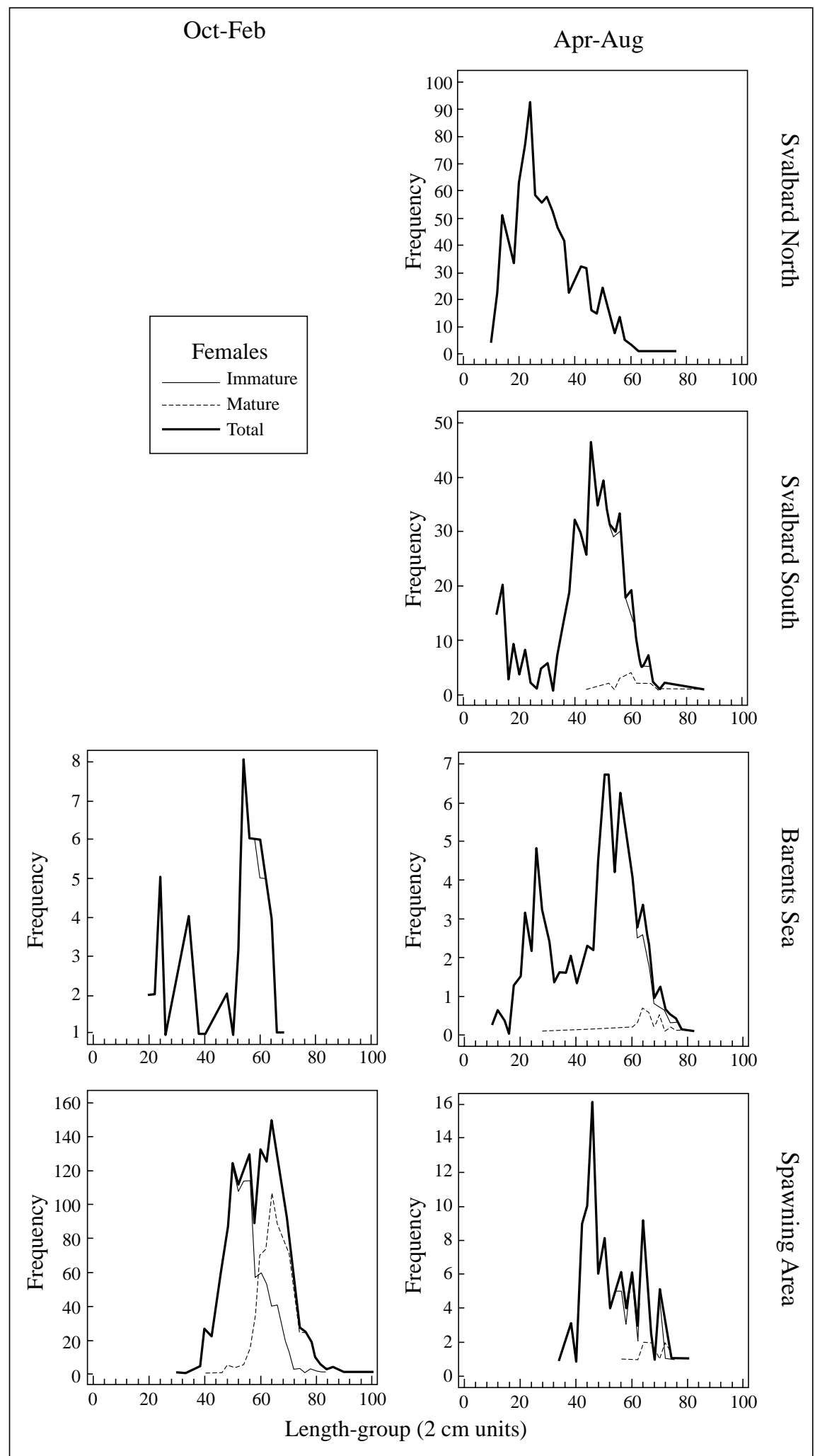

Fig. 2. Length compositions of female Greenland halibut from each area and sampling season. Frequency equals the number of individuals. All years combined. The immature class includes immature and early maturing, and the mature class includes close to spawning and spent. 


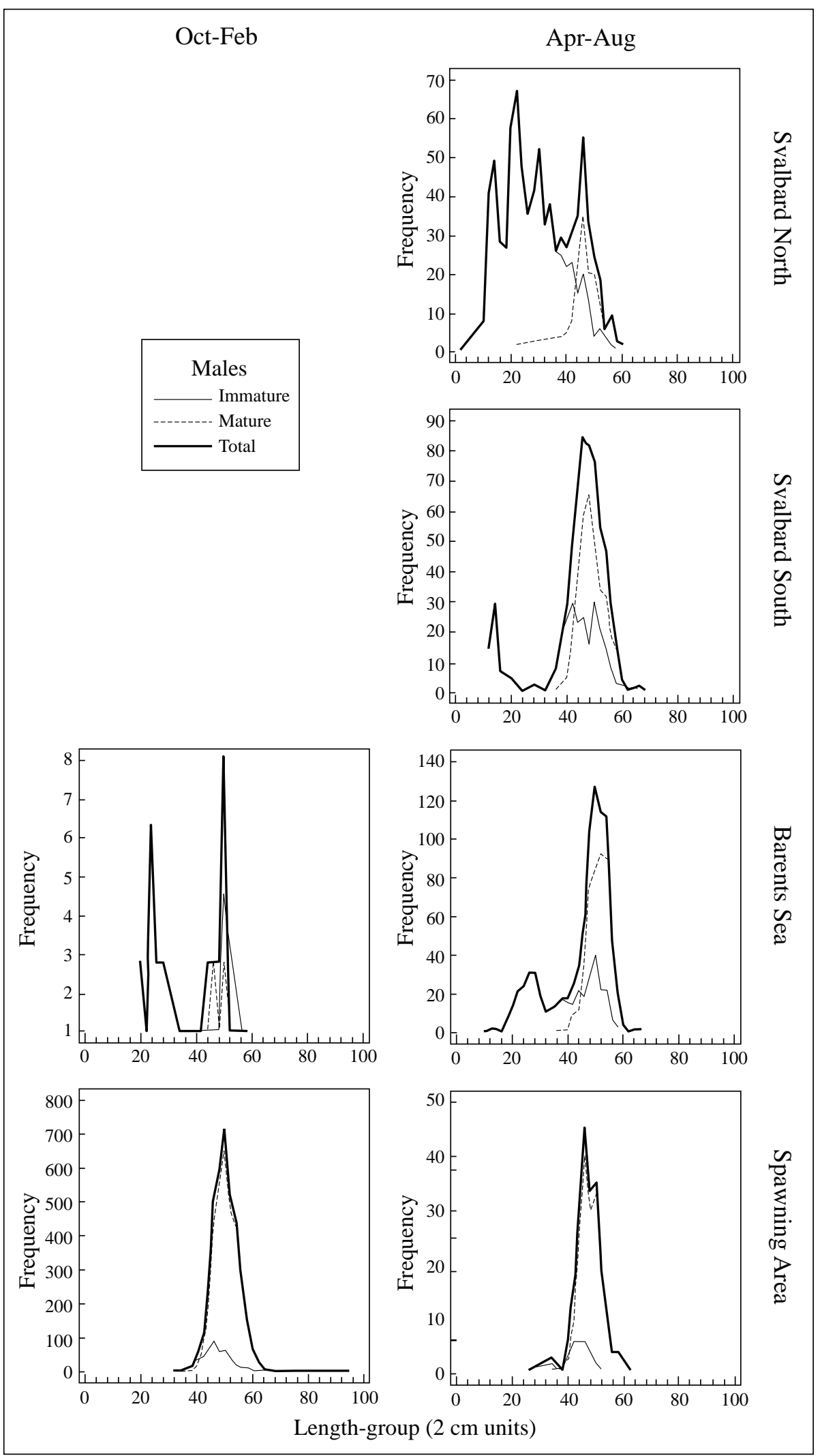

Fig. 3. Length compositions of male Greenland halibut from each area and sampling season. All years combined. 

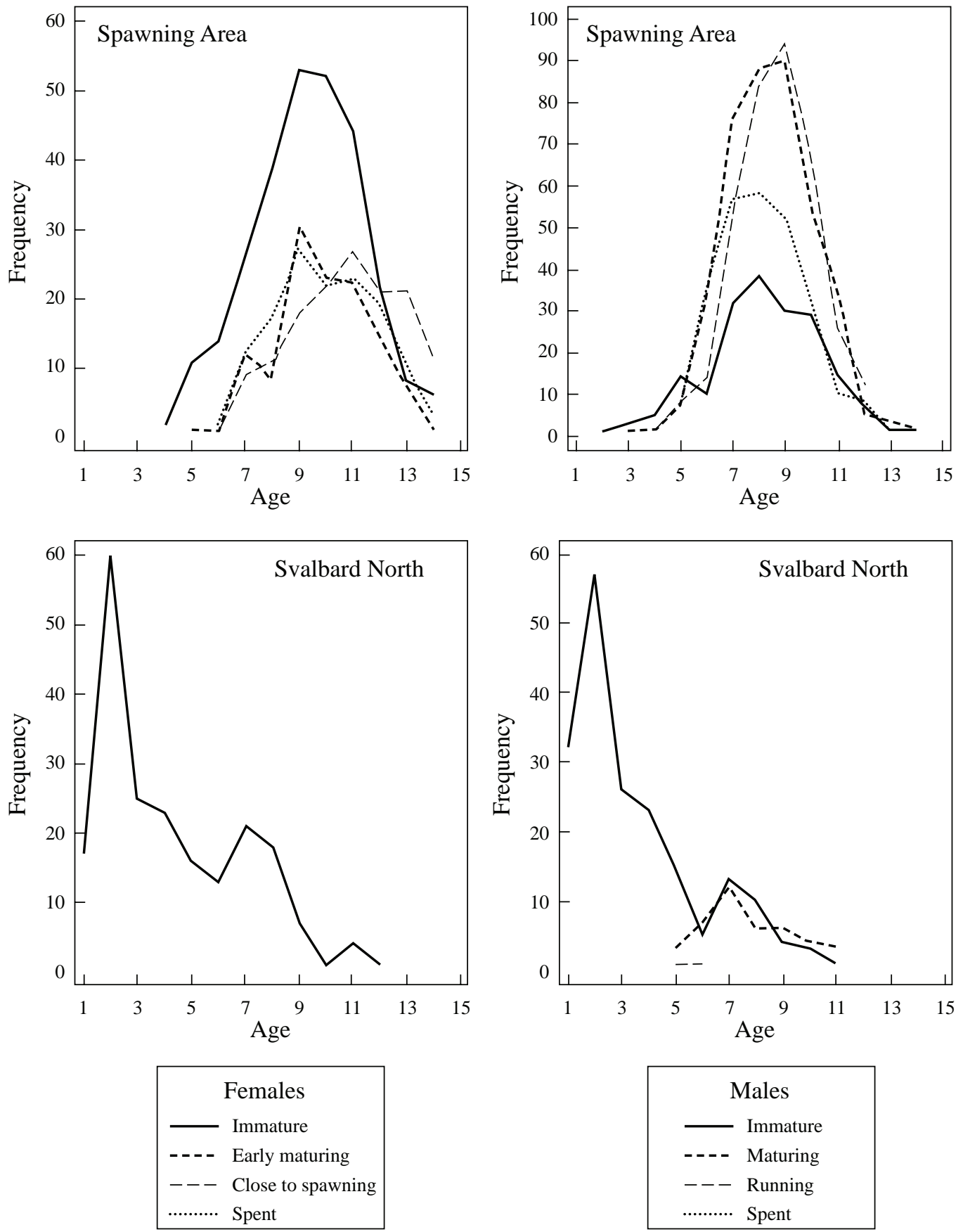

Fig. 4. Age composition of Greenland halibut from Svalbard North (Area 4) in April-August and Spawning Area (Area 1) in October-February. All years combined.

and mature ("Close to spawning" and "Spent") constituted two relatively well-separated modes with the Early Maturing females in between. The early maturing females were in the upper length range of the immature ones. All females that were at least $20 \%$ larger than the mean for their age-group were mature, while those that were $20 \%$ smaller than the mean of the age-group were all immature or early maturing. The mean length of immature females was $82 \%$ of the mature individuals of same age.

Figure 6 shows the mean length-at-age of Greenland halibut in different stages of their ontogeny. It shows that the fastest growing females arrive at the 

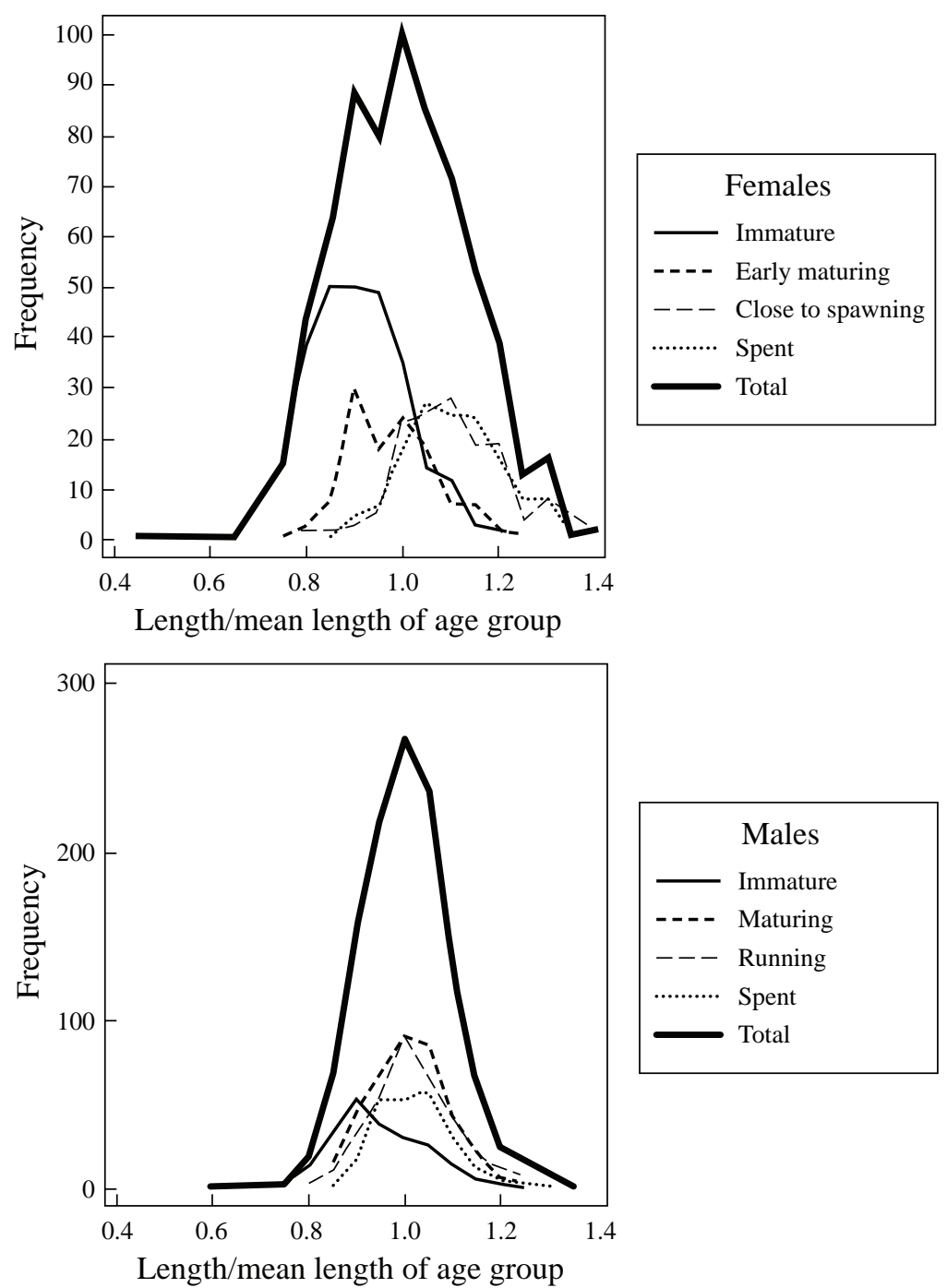

Fig. 5. Frequency distribution of relative length groups of male and female Greenland halibut of different maturity stage. Data from Spawning Area (Area 1) in October-January, all years combined. Units of 0.05 were used for the relative length groups.

spawning grounds at age 5 and spawn at age 7 . The slowest growing individuals in our data remained in the nursery area north of Svalbard at least up to age 9. The highest age estimate of females in Svalbard North was 12 years (Fig. 4). Figure 6 also shows that the Early Maturing females constituted a separate group, with mean length consistently between immature and mature females.

Males. In Svalbard North, most males were immature and younger than six years, whereas in the Spawning Area, age 7-10 represented the most common age groups of both mature and immature males and mature fishes numerically dominated (Fig. 4). The age composition of mature males in the Spawning Area was similar to that for the immature males. In Svalbard North the proportion mature was $50 \%$ for age six and older, but $0 \%$ below age 5 . The irregularities in the numbers-at-age curves in Svalbard North were mostly similar for males and females, i.e. modes at age 4 and 7-8 and low frequency at age 6 . An exception was age 1 , for which there were many more males recorded than females. However, most small fish $(<15 \mathrm{~cm})$ were classified as males and given the difficulties of sex-identification by visual macroscopic inspection at these lengths, it is 

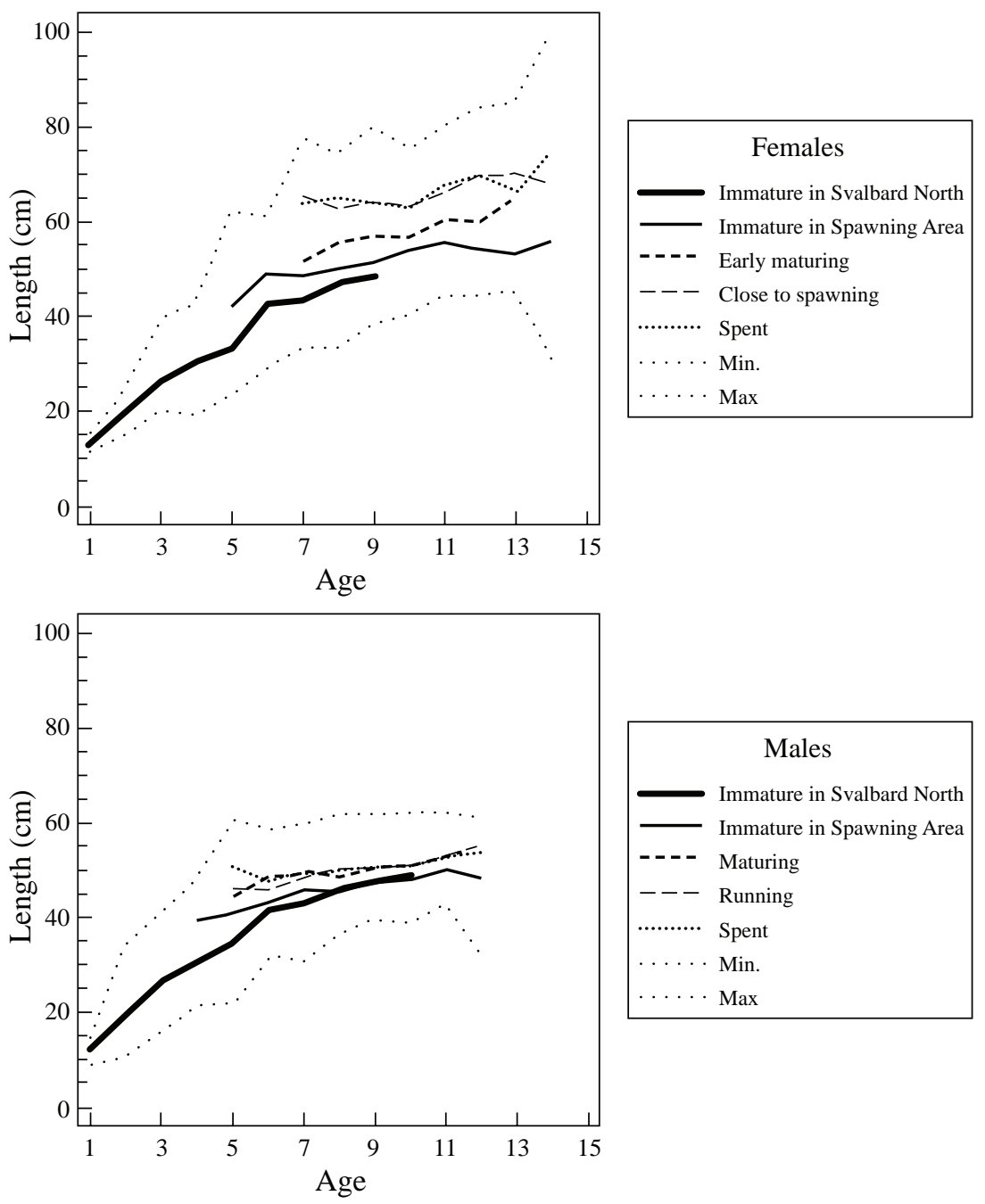

Fig. 6. Mean length-at-age of male and female Greenland halibut relative to maturity stage and sampling locality. The mean length-at-age for maturing, running and spent are for the Spawning Area in October-January.

reasonable to assume that this difference was mainly caused by misclassification.

At the spawning grounds in October-January, mean length of immature males of all age groups combined was $46 \mathrm{~cm}$, and mean length was $50 \mathrm{~cm}$ for those classified as Maturing, Running or Spent. The mean length-at-age of immature males in the Spawning Area was $90 \%$ of the mean length of individuals of the same age classified to a higher maturity stage. Figure 5 shows this for all age groups combined using relative length-at-age. The difference in mean length-at-age between immature and mature males was similar to that for the females, but the distributions overlapped much more than for females (Fig. 5).

The fastest growing males arrived at the spawning grounds at age 4 and spawned at age 5, whereas the slowest growing remained in the nursery area north of Svalbard at least up to age 10 (Fig. 6). The highest age estimate of males in Svalbard North was 11 years.

Figure 6 also shows that the minimum length-atage and the mean length of immature individuals in Svalbard North were similar for males and females. The main sex-difference in length-at-age was that for ages above 6 years, some females had a much higher growth than any males. 


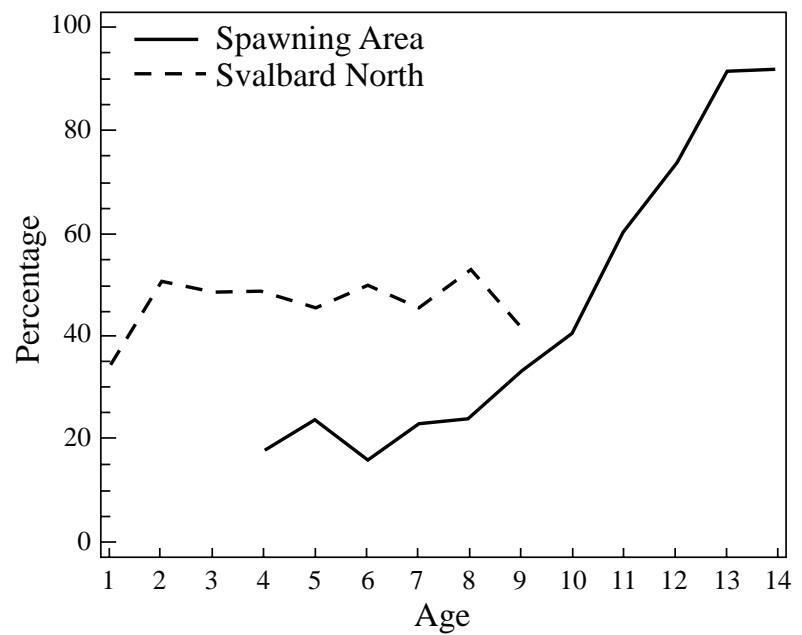

Fig. 7. Percentage females vs. age in Svalbard North (Area 4) and Spawning Area (Area 1).

\section{Sex composition}

Disregarding the probable mis-sexed one-yearolds (see above), the sex-composition in Svalbard North remained 50-50 up to age 9 (Fig. 7). At the spawning ground, percentage of females increased gradually with age. For age groups older than 10 years there were more females than males, and for those older than 12 years $90 \%$ were females.

\section{Discussion}

\section{Maturation, growth and migration}

It appears that migration and spawning of Greenland halibut is largely influenced by size and growth characteristics. The females left the northern nursery grounds when they approach $40 \mathrm{~cm}$ and appear in spawning condition at about $60 \mathrm{~cm}$. The transition occurred within a broad age-span. While the youngest female spawner recorded was age 7, the oldest immature was 14 years old. Males also migrate out from the nursery areas when they approached 40 $\mathrm{cm}$. They were largely mature at this size and were more widely distributed than mature females.

The growth indicated by the present analyses of length-at-age is similar to previous accounts. The growth curves estimated for the same stock in the same years in Bowering and Nedreaas (2001) pass approximately in the middle of the minimum and maximum observed length-at-age. Also those from
Milinsky (1944) and Kovtsova and Nizovtsev (1985) lie within the range observed in this work. However, given the broad range in length-at-age observed here, that may not be surprising. None of the other accounts reported the distribution of lengths around the meansat-age.

Since the fast growing individuals left the nursery and entered the Spawning Area first, as age increases, the length-at-age curves from both areas gradually consist of less fast-growing individuals. This is important to consider when establishing growth curves for this stock. Not only may the growth curve be biased due to non-proportional sampling of slow and fast growing individuals, but also between-year variation in growth estimates may result from changes in distribution of different parts of the population. Such changes may not be recognised in the surveys and may result in erroneous inferences about the growth in the stock. Albert et al. (2001b) and Albert and Høines (in print.) have shown that such variation in distribution relative to the surveys have occurred for younger agegroups of Greenland halibut. These distributional changes were related to variations in the physical environment (temperature and the Index of the North Atlantic Oscillation) and resulted in completely erroneous conclusions in the stock assessment. It may well be that corresponding effects also apply in the case of mature fish. Adult Greenland halibut seem more stenothermal than juveniles (Godø and Haug, 1989), and may thus be more susceptible to environmental changes.

In the Northwest Atlantic, Bowering (1983) found differences in growth between nearby geographical areas and Morgan and Bowering (1997) found that age at maturation varied inexplicably. The reason for variation in growth and maturation within a sex may be related to environmental variability, but may also be attributable to different individual strategies. Geographical differences in length- and maturity-atage may thus occur if distribution-at-age varies according to individual growth strategies. This study shows that migration is closely related to individual growth.

The variation in length-at-age, and therefore in growth rate, was much higher for females than for males. This was apparent both with the modal groups of 1-3 year old fish, where the internal variability within each modal group was less for males, and from the length-at-age distributions of older fish based on otoliths. At all ages, a large part of the slow-growing 
females had the same length-at-age as the males. In most previous studies in both Northeast and Northwest Atlantic, females have larger length-at-age than males from age 5-6 onwards (Bowering and Nedreaas, 2001). However, the actual estimates are dependent on the sampling areas relative to the distribution of all size classes within each sex and age group. This study has shown that distribution of mature males and females are very different, and therefore sampling design must address this sex difference. Thus most reported differences in mean length-at-age between sexes are probably biased.

However, this study does show a distinct sexdifference in growth for older fish. While females showed a continuous increase with age in both the lower and upper limits of length-at-age, males appeared to grow towards an asymptotic length of about $60 \mathrm{~cm}$. As in previous studies the central tendency levelled off after age 6. Krzykawski (1976) suggested that this was due to earlier maturation in males combined with a slowing of growth after maturity. This view was also held by Godø and Haug (1989), while Bowering and Nedreaas (2001) suggest that maturation may not be so influential on male growth as previous believed. It is possible that the levelling off in mean length-at-age is related to mortality more than to changes in growth rate of individual fish. Based on back-calculation of individual growth of long rough dab (Hippoglossoides platessoides), another long-lived flatfish, Fossen et al. (1999) suggested that the levelling off in the length-at-age curve was related to size-selective mortality. As for long rough dab, this paper shows that for Greenland halibut there appears to be a correlation between slow growth, delayed maturation and life expectancy. In the future, back-calculation from otoliths together with mark recapture experiments may prove useful to establish reliable estimates of growth and mortality of Greenland halibut.

\section{The early maturing females}

Combining information from a visual maturity index, an index of oocyte size and the gonadosomatic index (GSI), Albert et al. (2001a) showed that a separate group of early maturing females might be distinguished at the spawning ground during the spawning season. These early maturing females were characterized by having small $(<1 \mathrm{~mm})$ oocytes when other females had large (approx. $4 \mathrm{~mm}$ ) even-sized (Stene et al., 1999) transparent oocytes and were close to spawning. These two groups of oocytes were also described by Sorokin (1967) and Fedorov $(1968,1971)$ who stated that the small oocytes were released during spawning in the following year. However, this paper showed that the size-at-age distribution of these early maturing females coincided with the larger immature ones, and consisted of individuals with a history of slow or moderate growth rates. Most mature females have had high growth rates, so this early maturing group could not be representative of all next year's spawners. Based on the distribution of logarithmic GSI of the early maturing females, which were between the immature individuals and the spent ones, Albert et al. (2001a) suggested that the early maturing ones represented next year's first-time spawners. Rønneberg et al. (1998) found the small oocytes in spent ovaries together with residual eggs. These females may thus represent next year's repeatspawners. However, we still miss the fast growing individuals among next year's first-time spawners. They were apparently not present at the spawning ground a year before spawning.

\section{Consideration of sampling time and location}

In our study, females in Spawning Area in October-January showed a bi-modal length distribution. The lower mode consisted of immature females (including the Early Maturing ones), the upper of mature females. The lower mode coincided with the total length composition of males. Huse et al. (1999) sampled Greenland halibut along the slope in September 1996, using trawl, longline and gillnets of different mesh-sizes. In their data the lower mode was totally dominating in the trawl catches and the upper one in the gill-net catches, whereas catches from longline showed both modes. Sex and maturity compositions from each gear were in accordance with this.

The reason for this large difference in trawl composition is probably that few of the mature females were present in the Spawning Area in September compared to October-January. The length composition in trawl catches in September (Huse et al., 1999) resembled the one from April-August in our study. Thus, availability of mature females near the bottom in the Spawning Area seems to increase sharply just prior to the spawning peak in late-autumn. This is after the annual routine surveys that make the basis for stock assessments. It is obviously of crucial importance to know the migration dynamics of Greenland halibut in order to realistically model the 
maturation process and thus calculate the spawning stock biomass.

The length distribution in our samples from Spawning Area in October-January was similar to the combined un-weighted length-composition from all three gear types in Huse et al. (1999). Thus, it seems that all length-groups present in the area were sampled in our study. However, Huse et al. (1999) found a bellshaped selectivity of the sampling trawl. Therefore, it is very probable that our sampling under-represented part of the population. Accounting for a bell-shaped selectivity would have increased the relative abundance of the upper length-mode, and thus significantly increased the proportion of mature females.

Huse et al. (1999) gives a thorough discussion of several relevant mechanisms that may cause underrepresentative sampling of some parts of the Greenland halibut population (e.g. small fish lost under the sweeps, large fish avoiding the trawl, sizedependent vertical herding, older fish with previous experience, etc.). A related problem is the possible individual differences in residence time in the area sampled. It is particularly noteworthy that almost no running females were caught at the spawning grounds, only those just prior to or after spawning (Albert et $a l ., 2001 \mathrm{a})$. This suggests there is a need for behaviour models at the individual level, but also more descriptive knowledge on distribution and composition. Although Jørgensen (1997) only found the youngest Greenland halibut ( $<3$ years) pelagically, feeding studies clearly indicate that larger fish also have a pelagic distribution (Hovde et al., 2002, Michalsen and Nedreaas, 1998). In this respect it seems particularly important in the future to investigate the vertical dimension of distribution in relation to stock composition in terms of length, sex, age and maturity.

\section{Acknowledgements}

Margaret Treble and Steve Cadrin are thanked for valuable suggestions for improving the manuscript.

\section{References}

ÅDlandsviK, B., A. C. GUNDERSEN, K. H. NEDREAAS, A. STENE, and O. T. ALBERT. 1999. Modelling the advection and diffusion of eggs and larvae of northeast Arctic Greenland halibut. ICES C.M. Doc., No. K:03, 20 p.
ALBERT, O. T., and Å. HØINES, 2003. Comparing survey and assessment data: Consequences for stock evaluation of Northeast Arctic Greenland halibut. Scientia Marina, 67 (Suppl. 1): 171-180.

ALBERT, O. T., E. M. NILSSEN, K. H. NEDREAAS, and A. C. GUNDERSEN. 1997. Recent variations in recruitment of Northeast Atlantic Greenland Halibut (Reinhardtius hippoglossoides) in relation to physical factors. ICES C.M. Doc., No. EE:06, 22 p.

AlBERT, O. T., E. M. NILSSEN, A. STENE, A. C. GUNDERSEN, and K. H. NEDREAAS. 1998. Spawning of the Barents Sea/Norwegian Sea Greenland Halibut (Reinhardtius hippoglossoides). ICES C.M. Doc., No. $\mathrm{O}: 22,19 \mathrm{p}$.

Albert, O. T., E. M. NILSSEN, A. STENE, A. C. GUNDERSEN, and K. H. NEDREAAS. 2001a. Maturity classes and spawning behaviour of Greenland halibut (Reinhardtius hippoglossoides). Fish. Res., 51: 217-228.

ALBERT, O. T., E. M. NILSSEN, K. H. NEDREAAS, and A. C. GUNDERSEN. 2001b. Distribution and abundance of juvenile Northeast Arctic Greenland Halibut (Reinhardtius hippoglossoides) in relation to survey coverage and the physical environment. ICES Journal of Marine Science, 58: 1053-1062.

ANON. 1997. Report of the ICES/NAFO workshop on Greenland halibut age determination. ICES C.M. Doc., No. G:1, 53 p.

ASCHAN, M., and K. SUNNANÅ. 1997. Evaluation of the Norwegian Shrimp Survey conducted in the Barents Sea and the Svalbard area 1980-1997. ICES C.M. Doc., No. Y:07, $22 \mathrm{p}$.

BOWERING, W.R. 1983. Age, growth and sexual maturity of Greenland halibut, Reinhardtius hippoglossoides (Walbaum), in the Canadian Northwest Atlantic. Fish.Bull., 81(3): 559-611.

BOWERING, W. R., and K. H. NEDREAAS. 2000. A comparison of Greenland halibut (Reinhardtius hippoglossoides Walbaum) fisheries and distribution in the Northwest and Northeast Atlantic. Sarsia, 85: 61-76.

BOWERING, W.R., and K. H. NEDREAAS. 2001. Age validation and growth of Greenland halibut (Reinhardtius hippoglossoides (Walbaum)): A comparison of populations in the Northwest and Northeast Atlantic. Sarsia, 86: 53-68.

FEDOROV, K.Y. 1968. Oogenesis and the sexual cycle of the Greenland halibut. Trudy Polyarnogo NauchnoIssledovatel'skogo i Proekttnogo Instituta Morskogo Rybnogo Khozyaistva i Okeanografii im. N.M. Knipovicha (PINRO), 23: 425-451.

FEDOROV, K.Y. 1971. Zoogeographic characteristics of the Greenland halibut (Reinhardtius hippoglossoides (Walbaum)). Journal of Ichthyology, 11: 971-976.

FOSSEN, I., O. T. ALBERT, and E. M. NILSSEN. 1999. Back-calculated individual growth of long rough dab (Hippoglossoides platessoides) in the Barents Sea. ICES Journal of Marine Science, 56: 689-696.

GODØ, O. R., and T. HAUG. 1989. A Review of the Natural 
History, Fisheries and Management of Greenland halibut (Reinhardtius hippoglossoides) in the Eastern Norwegian and Barents Seas. Journal du Conseille International pour l'Exploration de la Mer, 46: 62-75.

GUNDERSEN, A. C., K. H. NEDREAAS, O. S. KJESBU, and O. T. ALBERT. 2000. Fecundity and recruitment variability of Northeast Arctic Greenland halibut during 1980-1998, with emphasis on 1996-98. Journal of Sea Research, 44: 45-54.

HOVDE, S. C., O. T. ALBERT, and E. M. NILSSEN. 2002. Spatial, seasonal and ontogenetic variation in diet of Northeast Arctic Greenland halibut (Reinhardtius hippoglossoides). ICES Journal of Marine Science, 59: 421-437.

HUSE, I., A. C. GUNDERSEN, and K. H. NEDREAAS. 1999. Relative selectivity of Greenland halibut (Reinhardtius hippoglossoides, Walbaum) by trawls, longlines and gillnets. Fish. Res., 44: 75-93.

ICES. 2001. Report of the Arctic Fisheries Working Group. ICES C.M. Doc., No. ACFM:2, 340 p.

JØRGENSEN, O. A. 1997. Pelagic occurrence of Greenland halibut (Reinhardtius hippoglossoides (Walbaum)), in West Greenland waters. J. Northw. Atl. Fish. Sci., 21: 39-50.

KOVTSOVA, M. V., and G. P. NIZOVTSEV. 1985. Peculiarities of growth and maturation of Greenland halibut of the Norwegian-Barents Sea stock in 19741984. ICES C.M. Doc., No. G:7, 16 p.

KRZYKAWSKI, S. 1976. A characteristic of growth of Greenland halibut, Reinhardtius hippoglossoides (Walbaum), from the North Atlantic. Acta Icthyologica et Piscatoria, Vol. VI, Fasc. 2, Szczecin, 1976: 80-101.
MICHALSEN, K., and K. H. NEDREAAS. 1998. Food and feeding of Greenland halibut (Reinhardtius hippoglossoides Walbaum)) in the Barents Sea and East Greenland waters. Sarsia, 83: 401-407.

MILINSKY, G. I. 1944. The biology and fisheries of Greenland halibut of the Barents Sea. Trudy Polyarnogo NauchnoIssledovatel'skogo i Proekttnogo Instituta Morskogo Rybnogo Khozyaistva i Okeanografii im. N.M. Knipovicha (PINRO), 8: 375-386, 1994, Translated by the Translation Bureau (ND), Foreign Languages Division, Department of the Secretary of State of Canada, Fisheries Research Board of Canada, Biological Station, St.John's, Nfld, 1968, 24 p.

MORGAN, M. J., and W. R. BOWERING. 1997. Temporal and geographic variation in maturity at length and age of Greenland halibut (Reinhardtius hippoglossoides (Walbaum)) from the Canadian Northwest Atlantic with implications for fisheries management. ICES J. Mar. Sci., 54: $875-885$.

RØNNEBERG, J. E., A. C. GUNDERSEN, and J. BOJE. 1998. Fecundity of Greenland halibut (Reinhardtius hippoglossoides) in the East Greenland waters. ICES C.M. Doc., No. O: 26.

SOROKIN, V. P. 1967. Some features of biology of Greenland halibut Reinhardtius hippoglossoides (Walbaum) in the Barents Sea. Materialy sessii ucenogo sovita PINRO, 8: 44-67.

STENE, A., A. GUNDERSEN, O. T. ALBERT, P. SOLEMDAL, and K. H. NEDREAAS. 1999. Early development of Northeast Arctic Greenland halibut (Reinhardtius hippoglossoides). J. Northw. Atl. Fish. Sci., 25: 171-177. 